\title{
Influence of Number of Wire Mesh Layers on the Behavior Strengthened Reinforced Concrete Columns
}

\author{
Dr. B. J. AL-Sulyfani， Dr. M. N. Mahmood, S. M. Abdullah \\ Civil Engineering Department \\ College of Engineering-Mosul University
}

\begin{abstract}
The main objective of the present experimental program is to study the behavior of reinforced concrete short columns subjected to combined axial load and flexure strengthened with ferrocement. To carry out the investigation, seven columns were tested. Out of which, one is the control un-strengthened column tested to failure to find out their load carrying capacity, six columns strengthened with ferrocement. The main objective of the present work is to investigate the effects of ferrocement thickness and number of wire meshes on the load capacity of those columns.

Increasing wire mesh layers from 2 to 5 causes an increase in the ultimate load of the strengthened column with ferrocement compared with the control column. Using $20 \mathrm{~mm}$ ferrocement thickness with a 5-wire mesh layers, the ultimate load increases $36.8 \%$ when compared with the control column. Similarly, for $30 \mathrm{~mm}$ ferrocement thickness with 5 wire mesh layers the increase is $48 \%$.
\end{abstract}

Key Words: Column, Ferrocement, Reinforced Concrete, Strengthening.

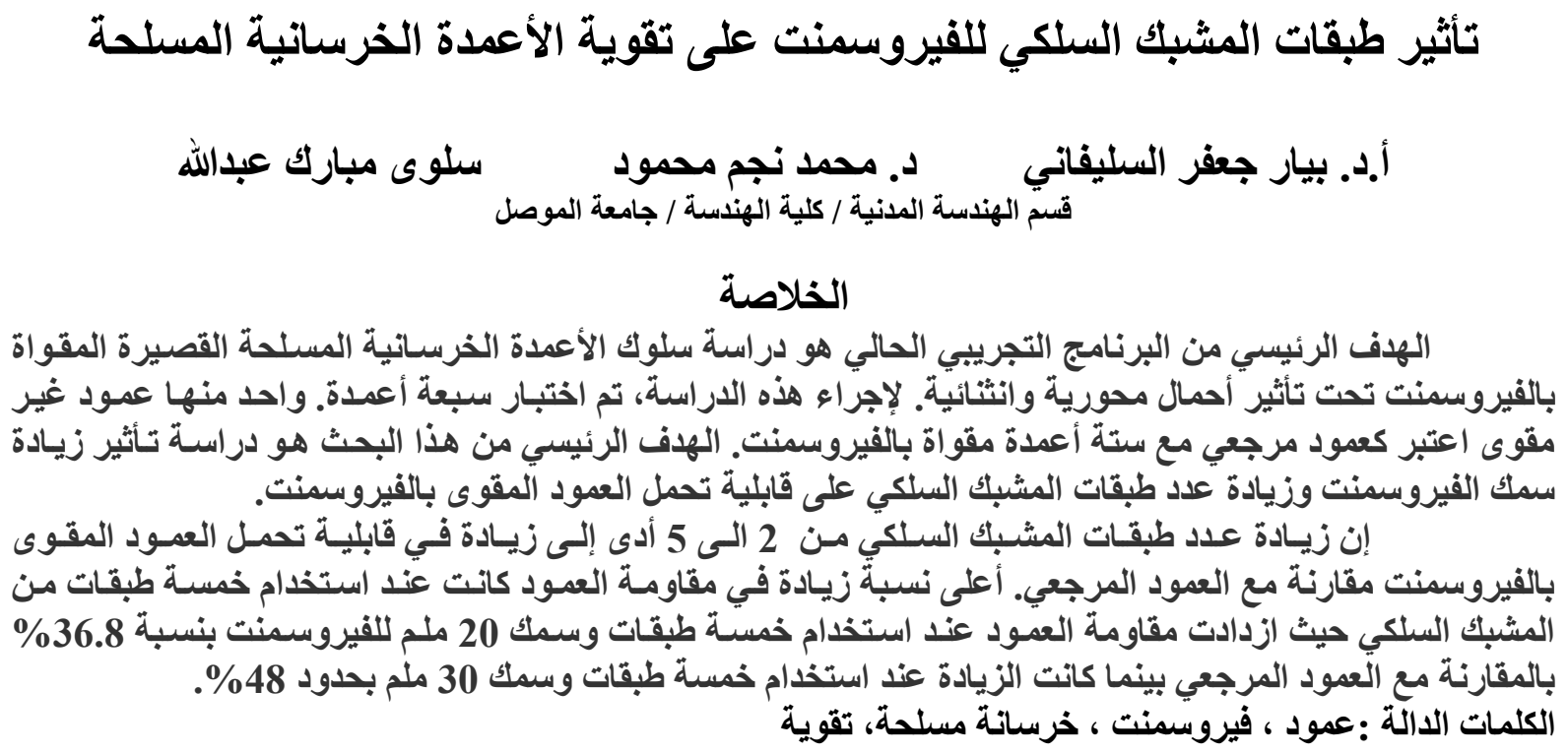


$\begin{array}{llll}\text { Al-Rafidain Engineering } & \text { Vol.21 } & \text { No. } 5 & \text { October } 2013\end{array}$

\section{Introduction:}

Reinforced concrete is one of the most abundantly used construction materials not only in the developed world but also in the remotest parts of the developing countries. The reinforced concrete structures constructed are often found to exhibit distress and suffer damages. These unserviceable structures require immediate attention, enquiry into the cause of distress and suitable remedial measures to bring the structure into its functional use again. In the last few decades, several attempts have been made all over the world to study these problems and to increase the life of the structures by suitable retrofitting and strengthening techniques. Ferrocement jacketing is found to be one of such attractive techniques due to its advantages, that is good tensile strength, lightweight, overall economy, water tightness, easy application and long life. Ferrocement is a type of thin walled reinforced cement mortar commonly constructed of hydraulic cement mortar strengthened with closely spaced layers of continuous and relatively small diameter wire mesh mainly of metallic materials.

In (2001), Takiguchi [1] described the results of a research effort on the strengthening of reinforced concrete columns susceptible to shear failure by using circular ferrocement jackets (CFJs). Based on 1:6 scale models, six identical reinforced concrete columns were fabricated. Two of these columns were tested under as-built conditions; the other four were strengthened by ferrocement with different number of wire mesh layers. All columns were tested under cyclic lateral forces and constant axial load. From test results, it was observed that both of the original columns suffered shear failure at low displacement ductility. By providing CFJs over the entire length, however, the displacement ductility of the columns was greatly improved.

In (2003) Abdullah and Katuski [2] had strengthened reinforced concrete columns with ferrocement jackets. They had used circular and square ferrocement jackets for strengthening square reinforced concrete columns with inadequate shear resistance. It was concluded that by providing external confinement over the entire length of reinforced concrete columns the ductility is enhanced tremendously.

In (2005) Mohammad and Reza [3] had performed a study to evaluate a retrofit technique for strengthening shear deficient short concrete columns. Ferrocement jacket reinforced with expanded steel mesh was used for retrofitting the columns. It has been found that expanded meshes were more effective than ties in shear strengthening of concrete columns and also specimens strengthened with expanded meshes showed distributed fine shear cracks and higher ductility capacity.

In (2007) Rathish et al. [4] carried out a research work, which forms part of experimental investigations aimed at developing an efficient and economical method of retrofitting existing reinforced concrete structures to enhance their shear resistance. A number of parameters including the axial load ratio affect the shear strength of reinforced concrete members. The aim was to examine the effect of axial load on the hysteretic response and energy absorption capacity of reinforced concrete and ferrocement confined columns. The external confinement using ferrocement resulted in enhanced stiffness, ductility, strength and energy dissipation capacity and the mode of failure could be changed from brittle shear failure to ductile flexural failure. The axial load value influences the hysteretic response of the columns and the energy absorption capacity. The effect of axial compression on column response was the acceleration of strength and stiffness degradation under repeated inelastic load cycles. 
In (2009), Kondraivendhan and Pradhan [5] investigated the use of ferrocement as an external confinement to concrete specimens. The effectiveness of confinement is achieved by comparing the behavior of retrofitted specimens with that of conventional specimens. The primary variable considered in the study, is concrete compressive strength. All other parameters such as size, shape, number of layers of wire mesh, and L/d ratio of the specimens were kept constant. The chosen section was circular cylinders with a size of $150 \mathrm{~mm} * 300$ $\mathrm{mm}$ and $\mathrm{L} / \mathrm{d}$ ratio of $6: 1$. The test results showed that the confined concrete specimens can enhance the ultimate concrete compressive strengths and failure strains.

In (2011), Long et al. [6] tested eleven full-size specimens including nine eccentrically compressed columns under monotonic loading and two axially compressed columns under laterally cyclic loading. From a series of comprising experiment of specimens strengthened with high performance ferrocement laminates (HPFL), and no strengthened specimens. It was found that the reinforced concrete columns strengthened with attached HPFL demonstrated greater degree of improving in load-bearing capacity, in which the carrying capacity increment of the strengthened eccentrically compressed columns with lesser eccentricity was greater than that of the same type of columns with higher eccentricity under the same strengthening conditions. The strengthening effects of the specimens with lower concrete grade are better than that of those with higher concrete grade; the ductility and energy dissipation ability of the strengthened columns were remarkably increased. The test results indicate that this category of strengthening reinforced concrete columns improved the ultimate load-bearing capacity, ductility, cracking behavior and mode of failure.

\section{Objective of the Research:}

The goal of the present work is to investigate the efficiency of strengthening reinforced concrete columns using ferrocement jacket with different numbers of chicken wire meshes (2, 3 and 5) layers through an experimental program and studying the effect of different ferrocement thickness $(20$ and $30 \mathrm{~mm}$ ) on the behavior of strengthened reinforced concrete column. To carry out the investigation, seven columns were prepared for the test. Out of which one is a reference column, tested to failure to find out its load carrying capacity. The experimental program of the present study consists of casting columns having a cross section of $250 \mathrm{~mm}$ depth, $150 \mathrm{~mm}$ width and $2350 \mathrm{~mm}$ overall height with hunch at each end. All the columns are reinforced with $4 \phi 12 \mathrm{~mm}$ diameter main reinforcement and $\phi 10$ ties spaced at $150 \mathrm{~mm} \mathrm{c} / \mathrm{c}$. The columns are tested under combined axial load and moment action by applying the load at a constant eccentricity of $225 \mathrm{~mm}$ as shown in Figure (1).

\section{Materials:}

Cement, fine aggregates, coarse aggregates, reinforcing bars were used in casting the columns. Cement mortar was used to strengthen the reinforced concrete columns by ferrocement jacket. Ordinary Portland cement was used in the present study. The physical properties of the cement comply with the IQS [7]. Locally available sand was used as fine aggregates both in the preparation of cement mortar and for the concrete mix. Sieve analysis of sand shows that it complies to (B.S882-1992) [8] having fineness modulus equal to 2.8. According to the additional limits of the specification mentioned above, the sand can be consider as coarse sand. Locally available gravel as coarse aggregate of $12 \mathrm{~mm}$ maximum 
size was used throughout the experimental study. Sieve analysis of coarse aggregate complies to the (B.S882-1992)[8]. Four bars of 12mm diameter steel having yield strength of (500) $\mathrm{MPa}$ and $695 \mathrm{MPa}$ ultimate strength was used as longitudinal steel as shown in Figure (2). Bars with $10 \mathrm{~mm}$ diameter are used for ties spaced at $150 \mathrm{~mm} \mathrm{c} / \mathrm{c}$. The properties of $10 \mathrm{~mm}$ diameter bars are same as that of $12 \mathrm{~mm}$ bars. The mix proportion (by weight) of concrete material are (1:1.5:2.8) (cement, sand, gravel) with water-cement ratio equal to (0.4) which gives slump between (100-150) $\mathrm{mm}$. This mix gives compressive strength at the age of 28 days equal to (31 MPa).

\section{Wire Mesh:}

Reinforcement of ferrocement is commonly in the form of layers of continuous mesh fabricated from single strand filaments. In the present work the locally available galvanized square woven wire mesh was used for ferrocement jacket. The chicken wire is of $0.6 \mathrm{~mm}$ diameter with $12 \mathrm{~mm}$ square mesh. The av was found to be (370) MPa. Volume fracti given in Tahle (1)
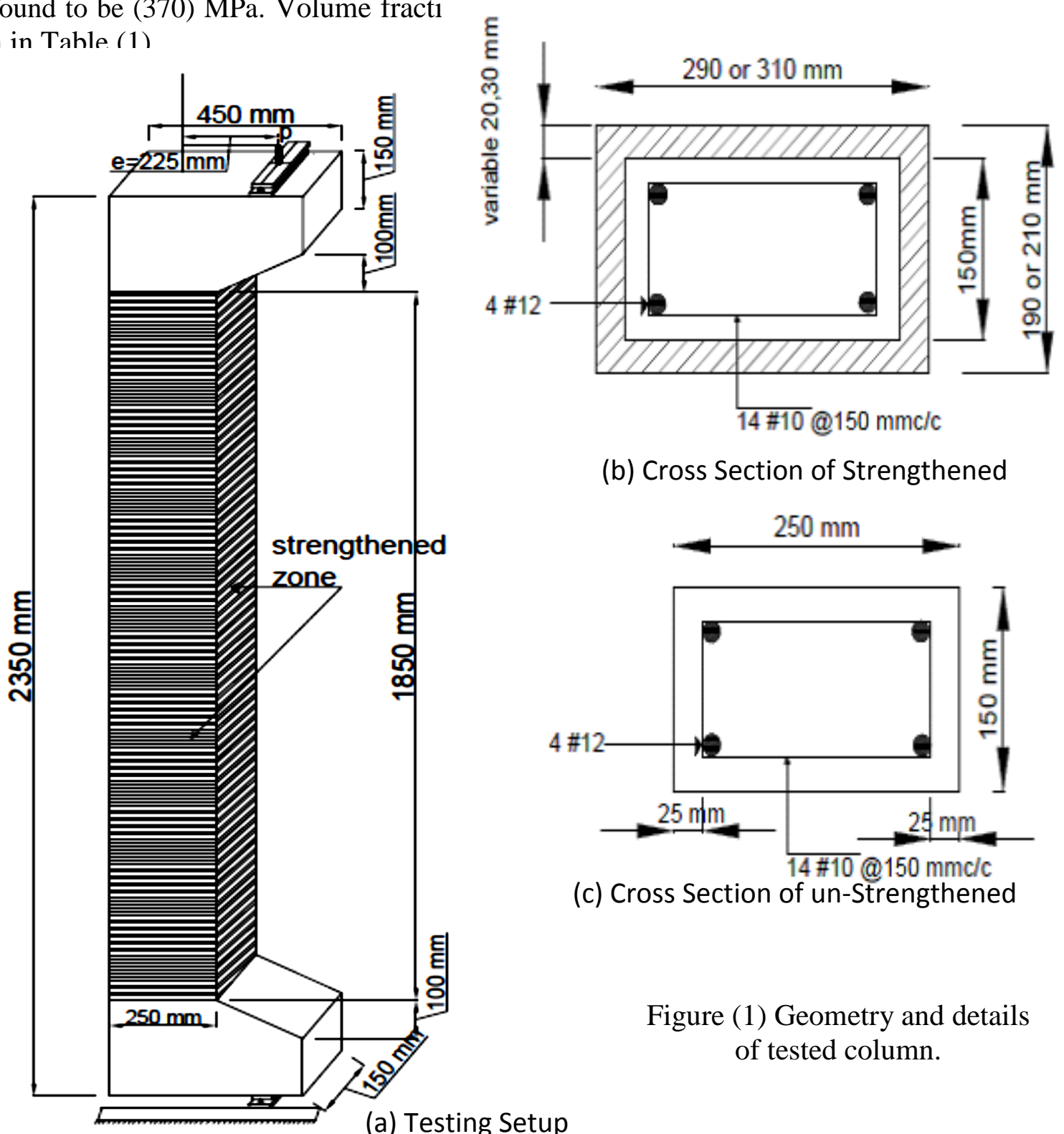

(b) Cross Section of Strengthened

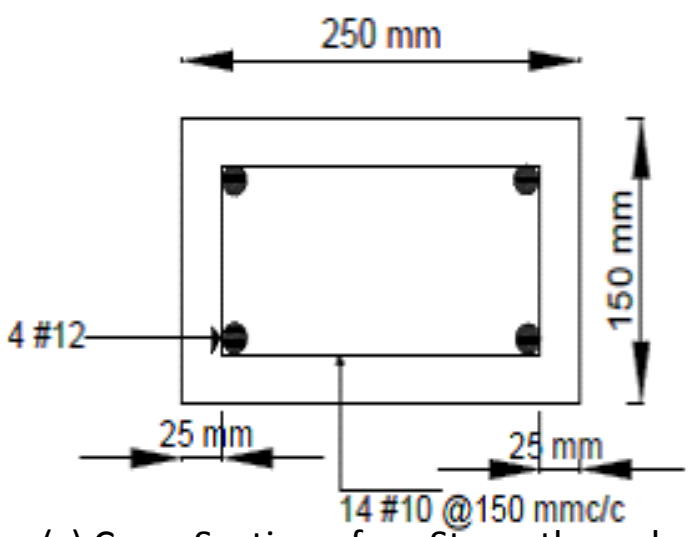

(c) Cross Section of un-Strengthened

Figure (1) Geometry and details of tested column. 


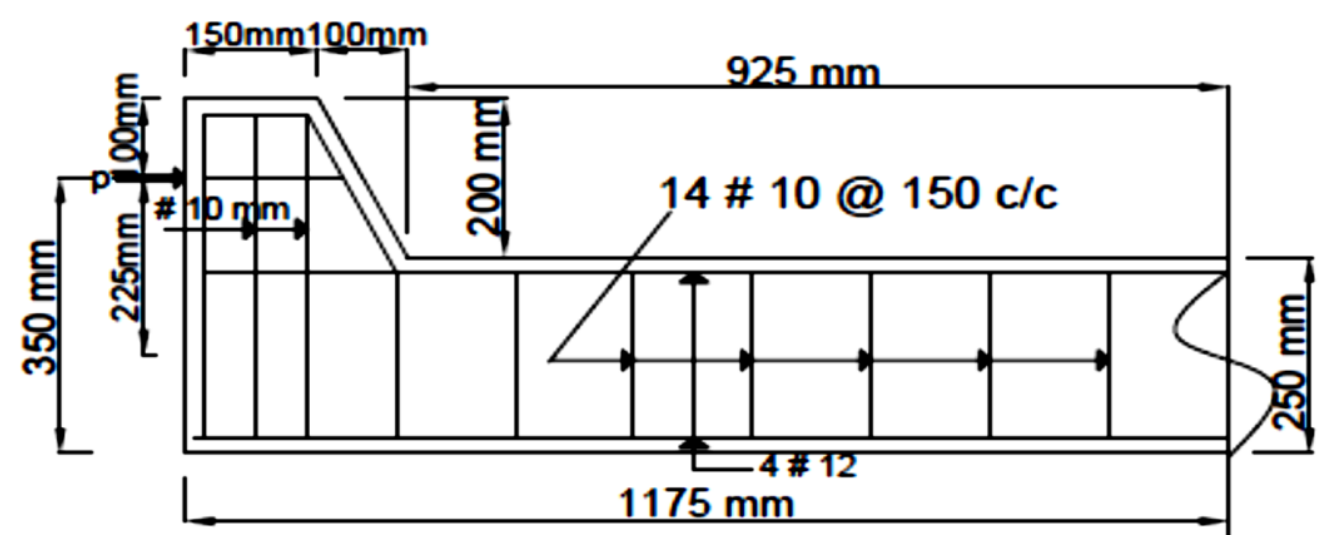

Figure (2) Longitudinal section of column

Table (1) volume fraction of wire mesh layers

\begin{tabular}{|c|c|c|c|}
\hline $\begin{array}{c}\text { Specimen } \\
\text { No. }\end{array}$ & Thickness $(\mathrm{mm})$ & $\begin{array}{c}\text { No. of } \\
\text { Layers }\end{array}$ & $\begin{array}{c}\text { Volume } \\
\text { Fraction }\left(\% \mathrm{~V}_{\mathrm{f}}\right)\end{array}$ \\
\hline C2 & 20 & 2 & 0.002355 \\
\hline C3 & 20 & 3 & 0.0035325 \\
\hline C4 & 20 & 5 & 0.0058875 \\
\hline C5 & 30 & 2 & 0.0015 \\
\hline C6 & 30 & 3 & 0.002355 \\
\hline C7 & 30 & 5 & 0.00375 \\
\hline
\end{tabular}

\section{Casting of Reinforced Columns}

The columns were cast in moulds $150 \times 250 \times 2350 \mathrm{~mm}$. First of all, the entire column mould is oiled, so that specimens can be easily removed from the mould after 24 hours. Spacers of $25 \mathrm{~mm}$ are used to provide uniform cover to the reinforcement as shown in Fig. (3). When the bars have been placed in position, the concrete mix is poured into the mould and compacted with the help of a needle vibrator. The moulds were stripped off after 24 hours and the columns are moist cured for (28) days using wetted jute bags.

\section{Description of Test Setup:}

All seven columns were tested under combined axial load and bending moment. The testing of columns was carried out using hydraulic operated jack connected to load cell. The load is applied to the column with the help of load cell and its value is recorded from a data logger system, which is attached to the load cell. Three transducers were placed at three locations, one is placed at the center and the other two were placed at a distance of span/3 from both ends. The value of deflection is obtained from these transducers. Out of these seven columns one is a control column, which is tested after 28 days of moist curing to find out its load carrying capacity. The experimental set up is shown in Figure (4) and details of jack and load cell are shown in Figures (5 and 6) while Figure (7) shows the control column at the failure stage. 
No. 5

October 2013

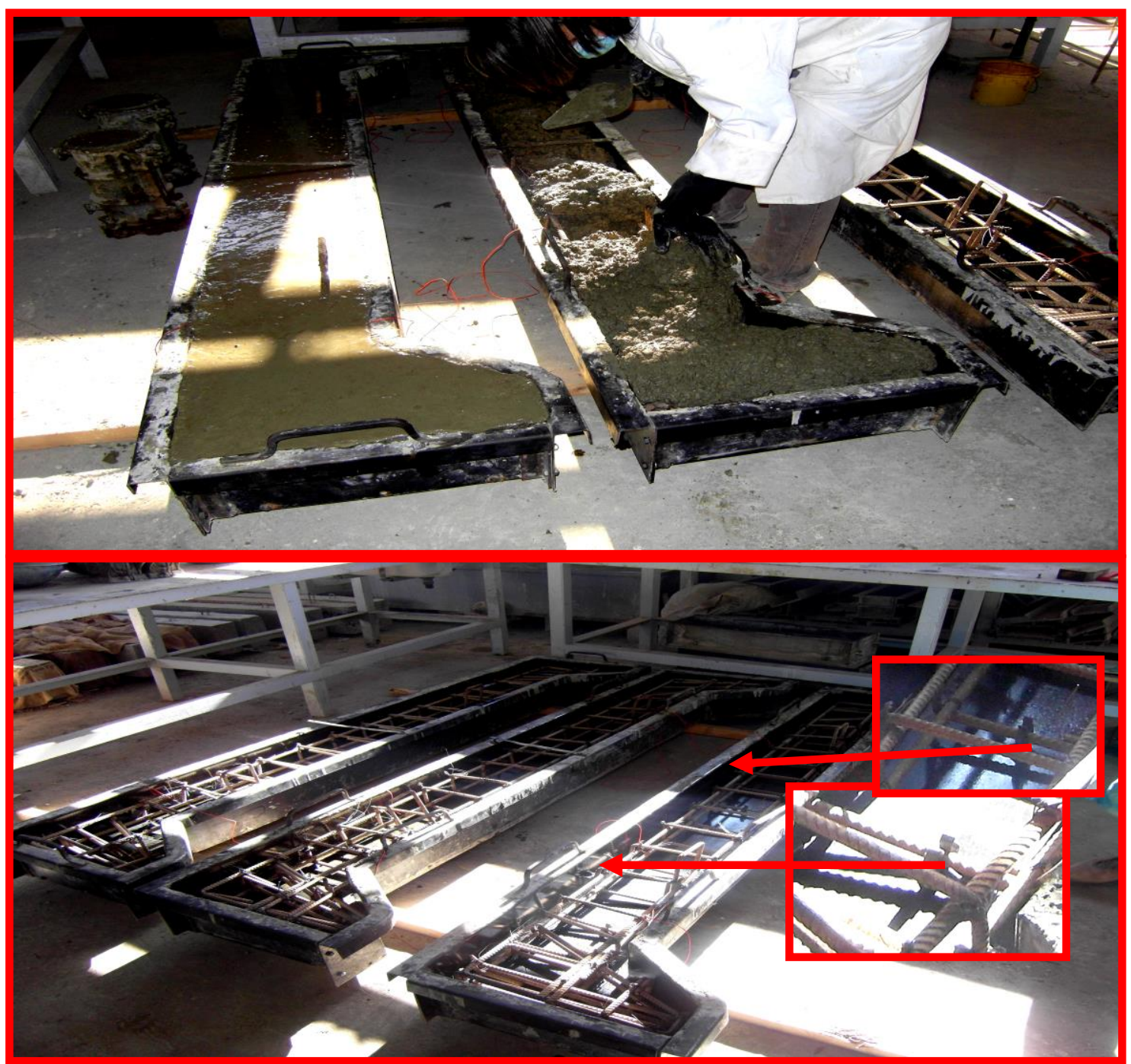

Figure (3) Columns Casting.

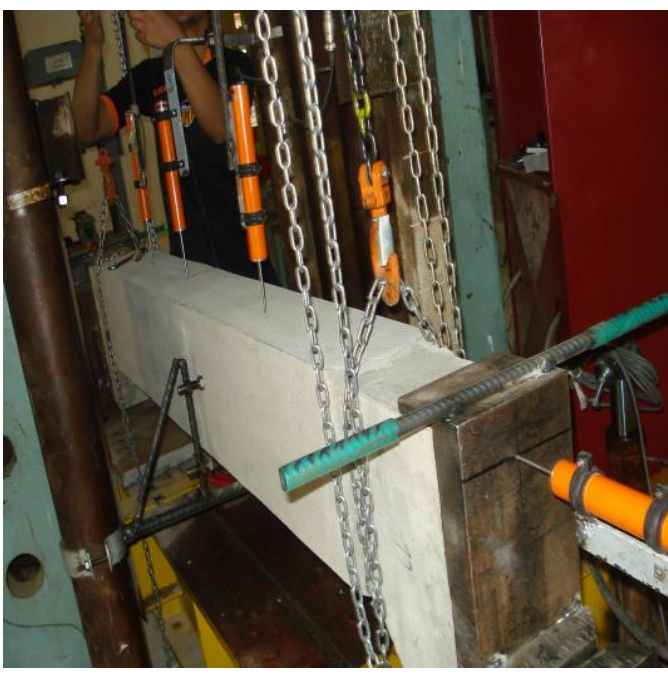

Figure (4) Experiment Set up Showing Position of Transducers.

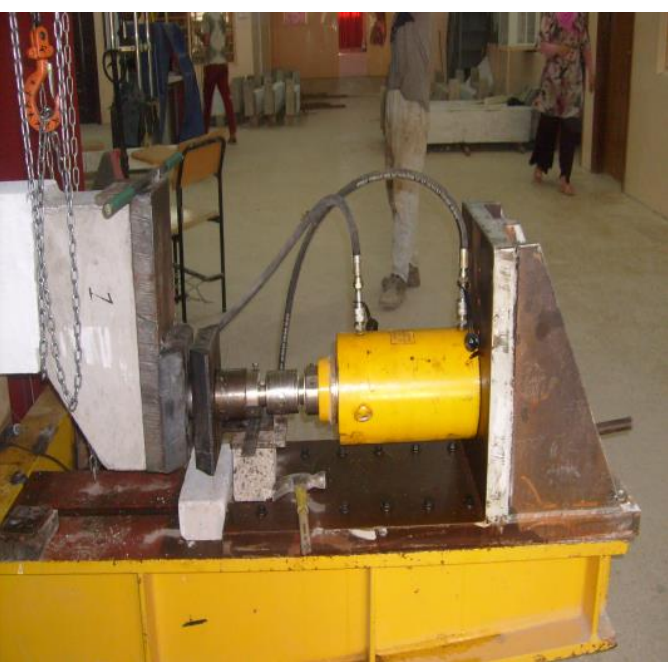

Figure (5) Set up of Jacking. 


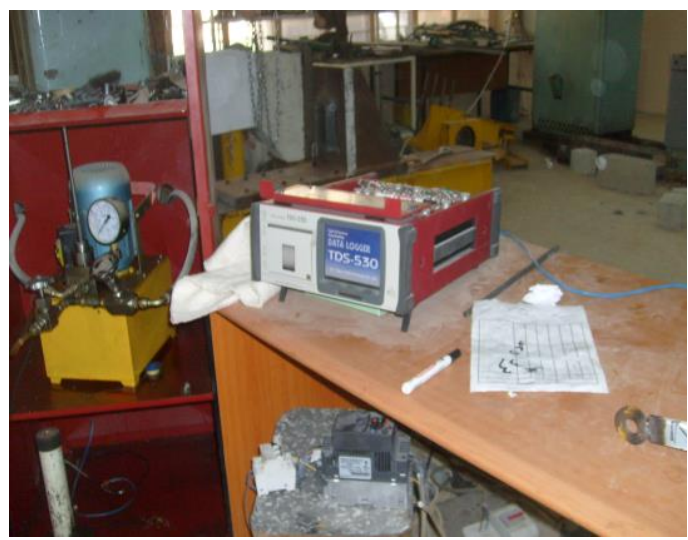

Figure (6) Data Logger System.

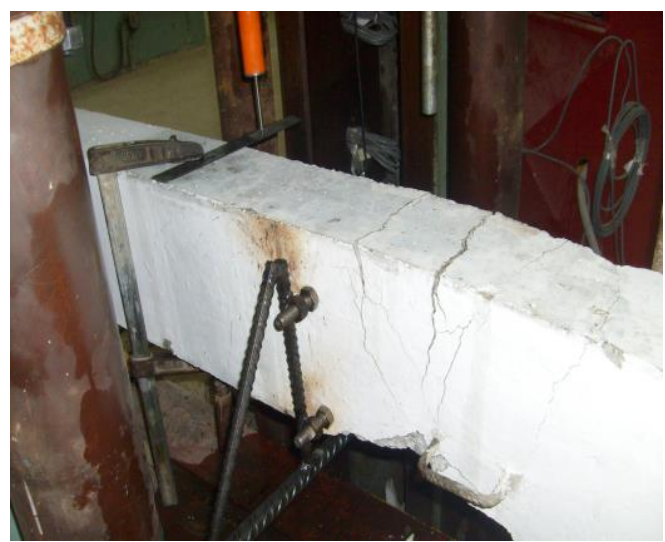

Figure (7) Failure of Control Colu

\section{Results and Discussion:}

\section{Un-strengthened Column Behavior:}

Figure (8) shows mid-height load deflection curve for the control column (C1). From this Figure the ultimate applied load is equal to $163 \mathrm{kN}$. Cracks are initiated at mid-height of the column followed by concrete crushing and the failure mode is shown in Figure (9) which depicts that the column failed by flexure. Crushing of concrete took place just prior to failure load as shown in Figure (9).

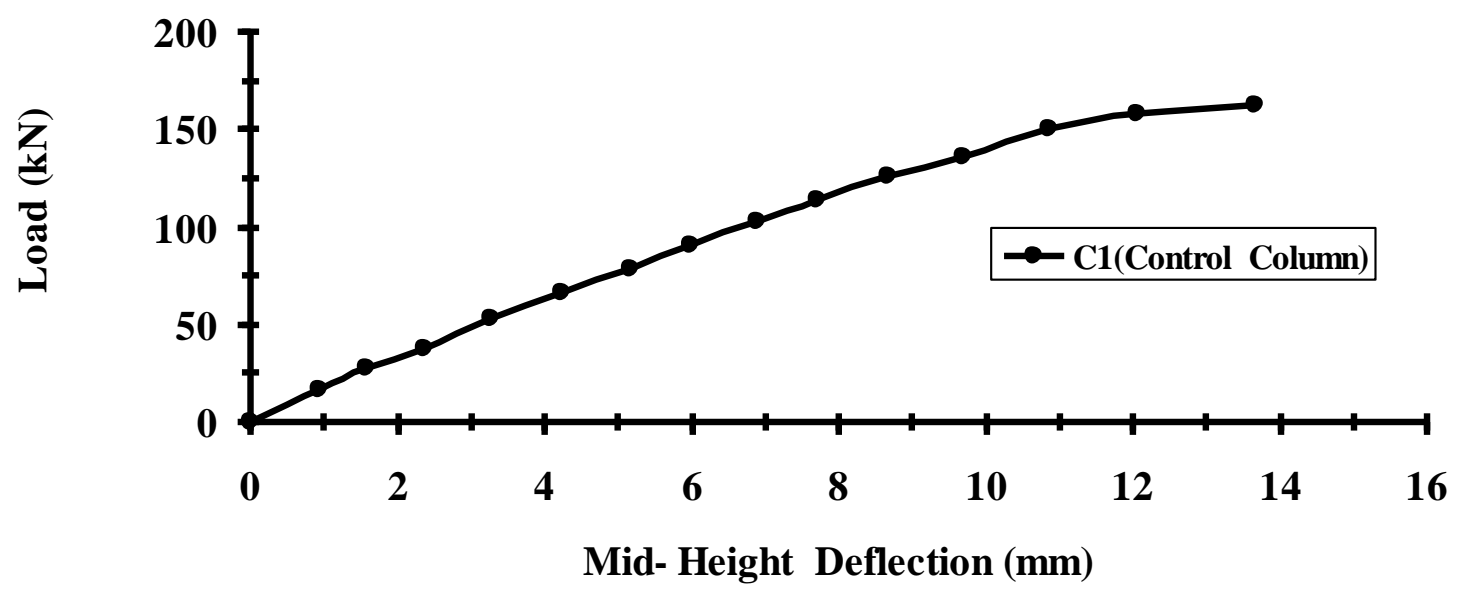

Figure (8) Load -Deflection Curve at Mid-Height of the Un-strengthened Column (C1).

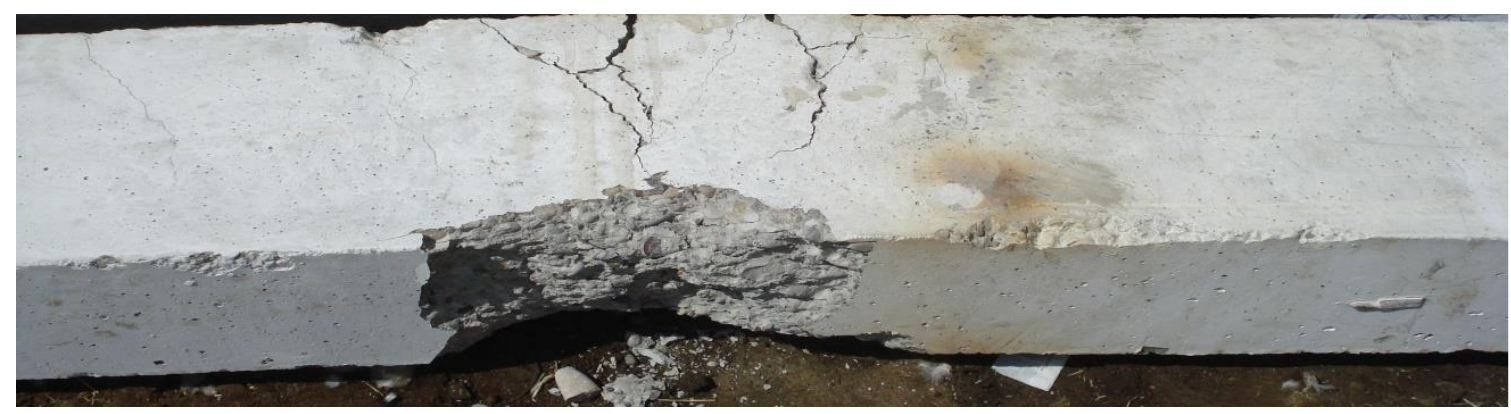

Figure (9) Crack pattern at failure for un-strengthened column C1. 
$\begin{array}{llll}\text { Al-Rafidain Engineering } & \text { Vol.21 } & \text { No. } 5 & \text { October } 2013\end{array}$

\section{Strengthened Columns Behavior:}

Figure (10) shows the load-deflection curves at mid-height of strengthened columns (C2, C3, C4) compared with the control column C1 . Column C2 failed at an ultimate load of $195.5 \mathrm{kN}$ with a strength increase of about $20 \%$ compared with the un-strengthened column (C1). During loading, the cracks spread along the entire length of column(C2) propagated from the tension face of the column as shown in Figure (11).

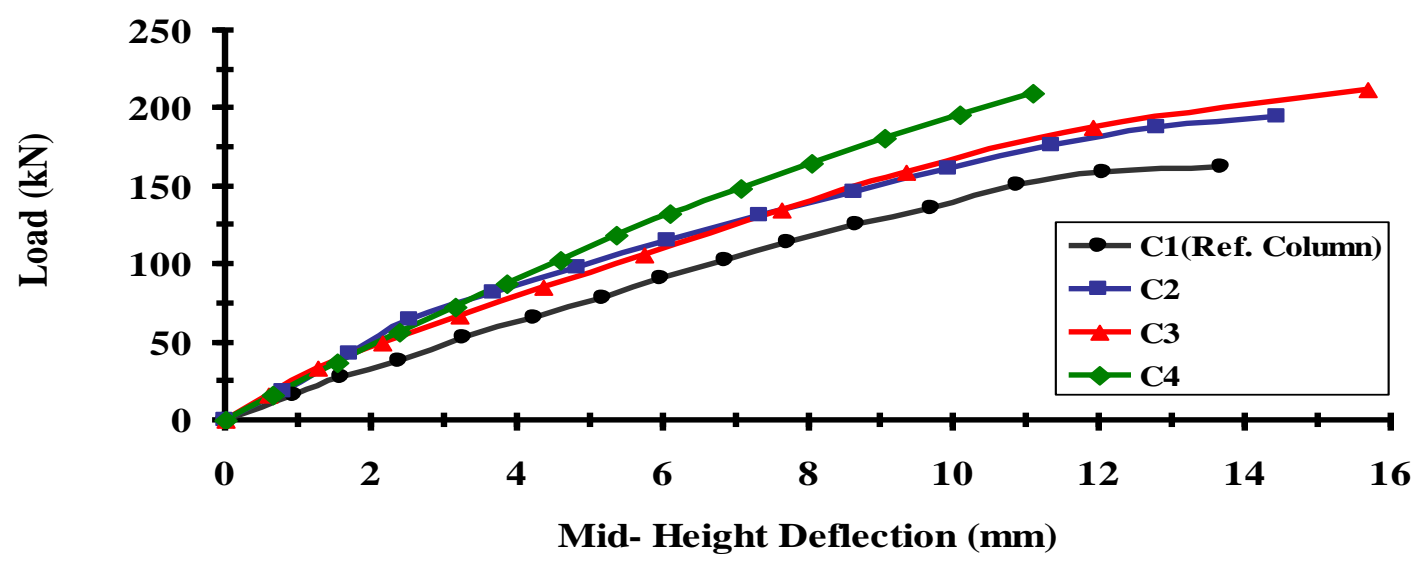

Figure (10) Load - deflection curve at Mid-Height of the columns C1, C2, C3, C4.

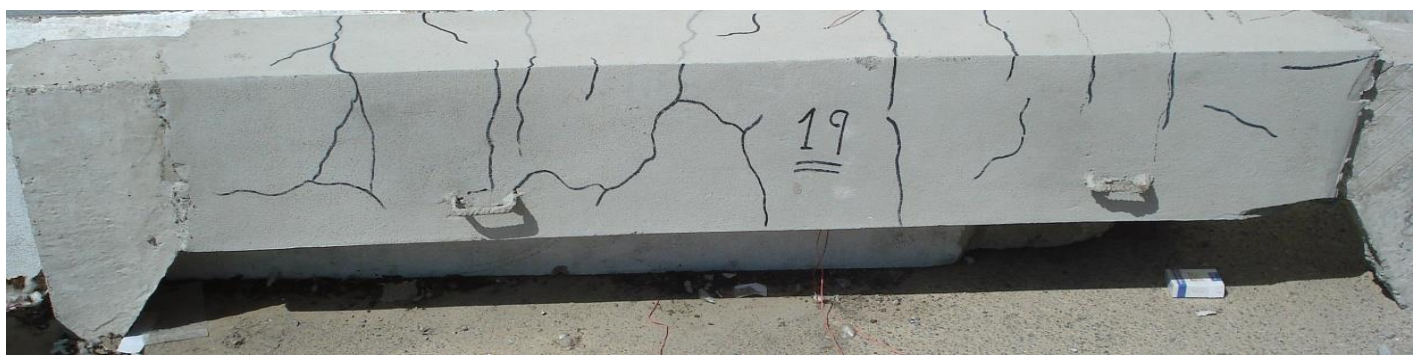

Figure (11) Crack pattern at failure for column $\mathbf{C 2}$.

Figure (10) shows the ability of column (C3) to resist an ultimate load of $209.3 \mathrm{kN}$ with an increase by about $28.4 \%$ compared with that of the un-strengthened column (C1). Figure (12) shows the cracks that spread at both sides of the column and spalling of the ferrocement layer in the tension face of the column.

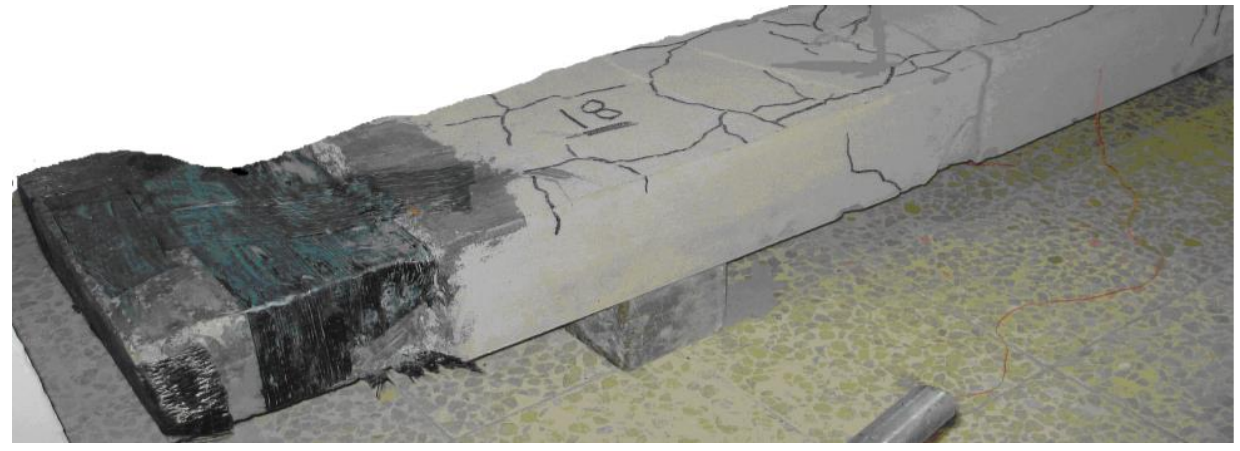

Figure (12) Crack pattern at failure for column C3. 
Figure (10) shows that column $(\mathbf{C 4})$ failed at an ultimate load equal to $213 \mathrm{kN}$ with an increase of about $30.6 \%$ compared with that of the un-strengthened column (C1). Cracks normal to the axis of the column propagated through the entire depth of the column and gradually widened at mid-height causing tension failure without concrete crushing as shown in Figure (13).

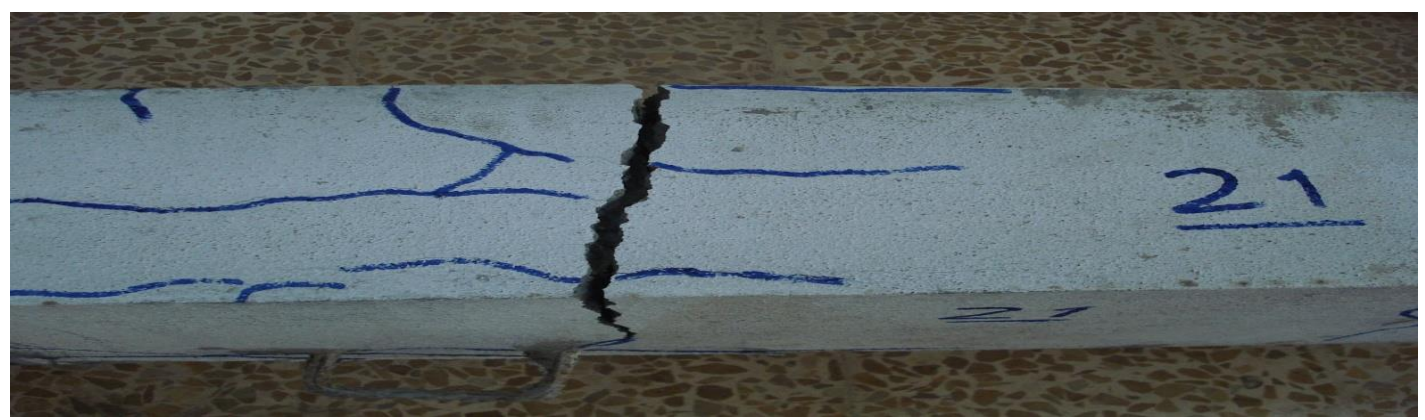

Figure (13) Crack pattern at failure for column C4.

For a summary of relative data of columns $(\mathbf{C 1}, \mathbf{C 2}, \mathbf{C 3}, \mathbf{C 4})$ refer to Table (2). It is clear from this Table that the 5 wire mesh layers with $20 \mathrm{~mm}$ ferrocement thickness strengthened the column and caused to increased the ultimate load by about $30.6 \%$ more than that of the un-strengthened column.

Figure (14) shows the load-deflection curves at mid-height of the column (C5,C6, C7) compared with the control column C1. The Figure shows that column C5 was able to resist an ultimate load equal to $195.5 \mathrm{kN}$ with an increase of about $20 \%$ compared with that of the control column. The failure mechanism of the column (C5) was by spreading the cracks on all faces of the column and finally spalling of the ferrocement near the bracket as shown in Figure (15).

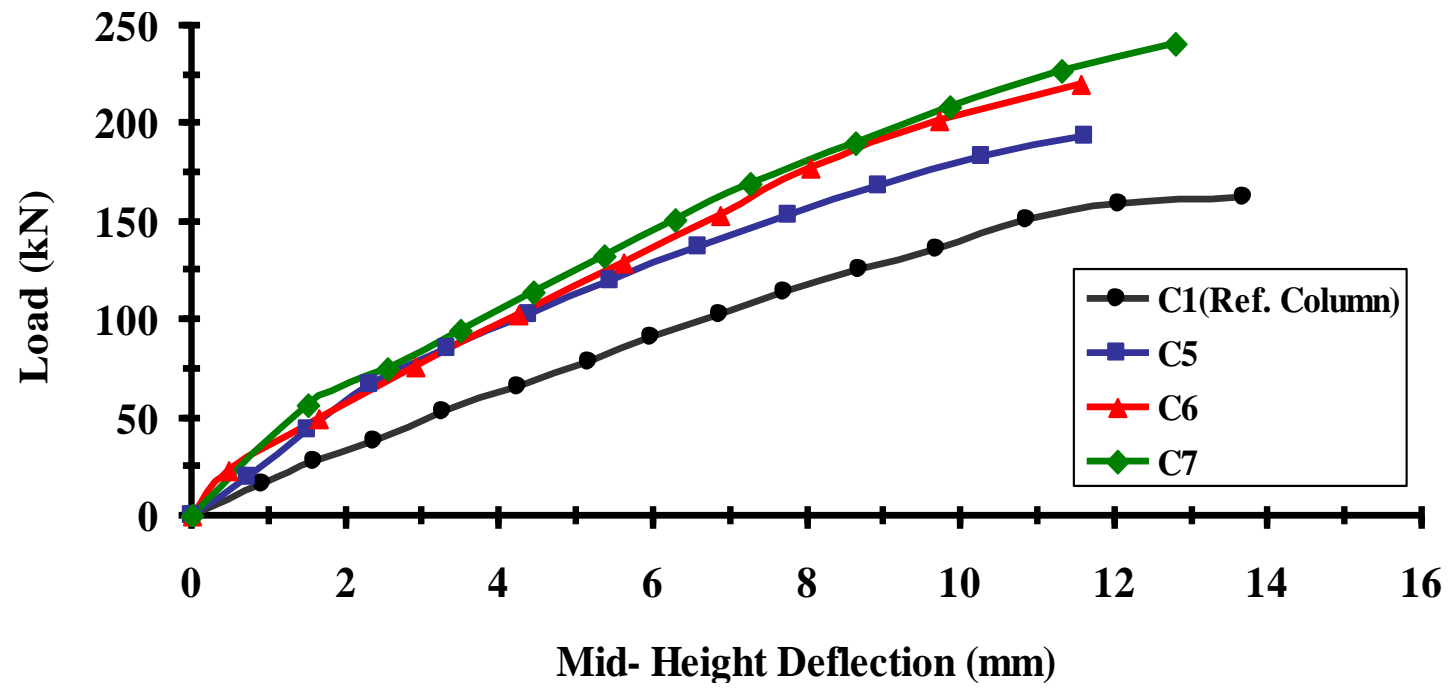

Figure (14) Load- deflection curve at Mid-Height of the columns C1, C5 ,C6 ,C7. 


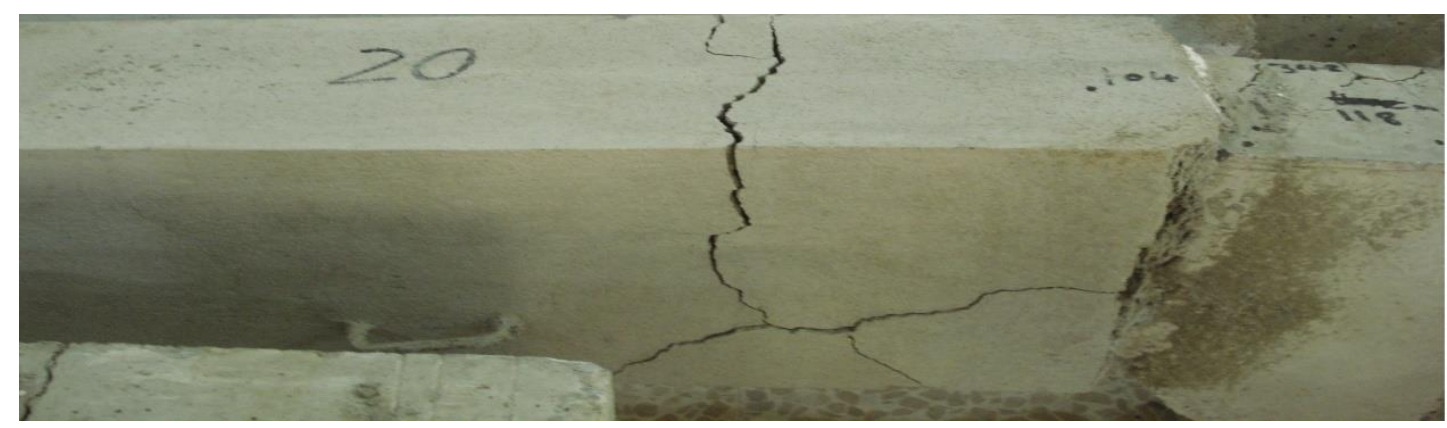

Figure (15) Crack pattern at failure for column C5.

Figure (14) shows that the strength of column (C6) was significantly increased. The column failed at an ultimate load equal to $219.8 \mathrm{kN}$ with an increase of about $34.8 \%$ compared with the ultimate load of the un-strengthened column (C1). Figure (16) shows the crack patterns for (C6). During loading, the cracks propagated through side faces of the column causing tension failure.

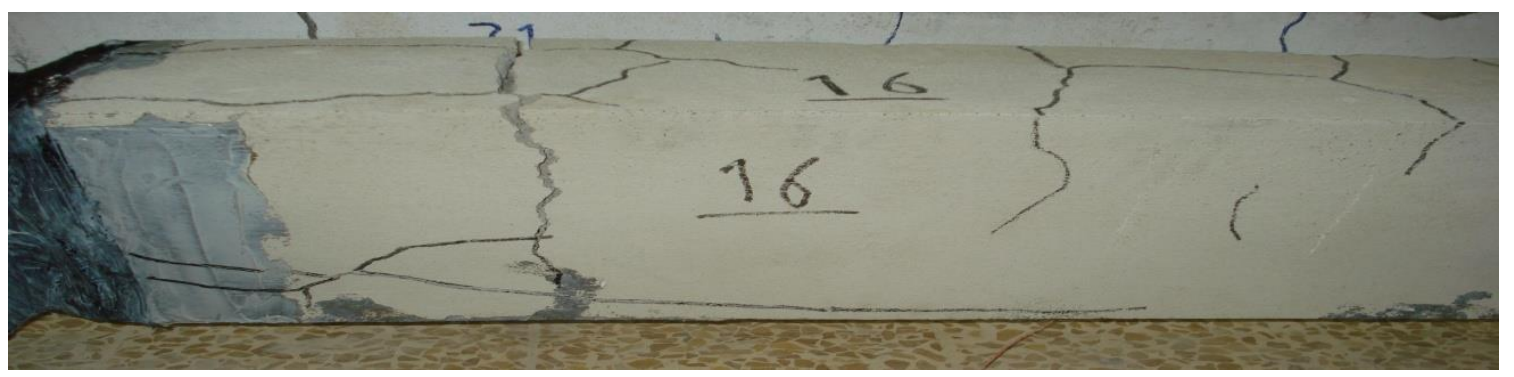

Figure (16) Crack pattern at failure for column C6

Figure (14) shows that the strength of column (C7) was also significantly increased. The column failed at an ultimate load equal to $241.1 \mathrm{kN}$ with an increase of about $48 \%$ compared with the ultimate load of un-strengthened column (C1).During loading, cracks propagated from the tension side of the column (C7) followed by crushing of ferrocement at the compression side of the column as shown in Figure (17).

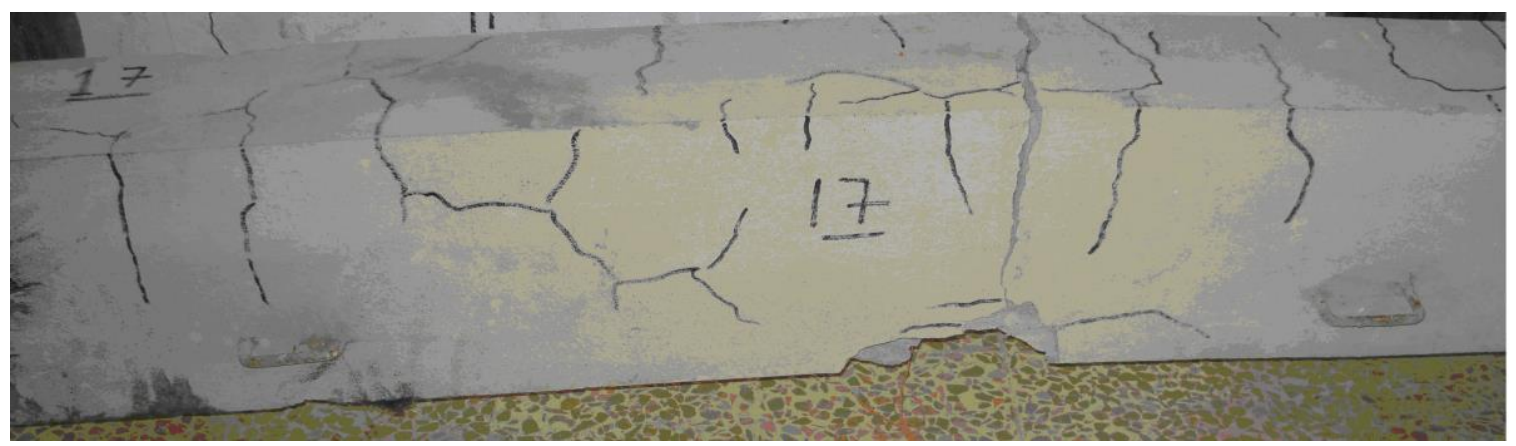

Figure (17) Crack pattern at failure for column C7.

For a summary of relative data of columns $(\mathbf{C 1}, \mathbf{C 5}, \mathbf{C 6}, \mathbf{C 7})$ refer to Table (2). It is clear from this Table that the 5 wire mesh layers with $30 \mathrm{~mm}$ ferrocement thickness 
strengthened the column to resist an ultimate load more than the other columns giving an increase of about $48 \%$ more than that of the un-strengthened column C1.

Table (2) also provides a summary of ultimate loads of all tested columns together with the relative percentage increase in ultimate loads compared with the reference column and modes of failure. Also the table contains the theoretical nominal load capacity calculated based on ACI code provisions using the material properties and the adopted load eccentricity.

Table (2) Ultimate loads of tested columns and percentage increase with respect to reference column and failure modes.

\begin{tabular}{|c|c|c|c|c|c|c|}
\hline $\begin{array}{c}\text { Column } \\
\text { No. }\end{array}$ & $\begin{array}{c}\text { First } \\
\text { cracking } \\
\text { Load } \\
(\mathrm{kN})\end{array}$ & $\begin{array}{c}\text { Experimental } \\
\text { ultimate } \\
\text { Load } \\
(\mathrm{kN})\end{array}$ & $\begin{array}{c}\text { Ferrocement } \\
\text { Thickness } \\
\mathrm{mm}\end{array}$ & $\begin{array}{c}\text { Percentage } \\
\text { increase in } \\
\text { Ultimate load }\end{array}$ & $\begin{array}{c}\text { Pn kN } \\
\text { based on } \\
\text { ACI Code }\end{array}$ & $\begin{array}{c}\text { Mode of } \\
\text { failure }\end{array}$ \\
\hline $\begin{array}{c}\text { C1 Ref. } \\
\text { column }\end{array}$ & 33 & 163 & & & 162.7 & $\begin{array}{c}\text { Tension Failure } \\
\text { +Crushing }\end{array}$ \\
\hline C2 2layers & $\mathbf{2 7 . 8}$ & 195.5 & 20 & $20 \%$ & 185.8 & Tension Failure \\
\hline C3 3 layers & 44.9 & 209.3 & 20 & $28.4 \%$ & 199 & Tension Failure \\
\hline C4 5 layers & 34.4 & 213.1 & 20 & $30.6 \%$ & 222 & $\begin{array}{c}\text { Spalling of } \\
\text { Ferrocement+ } \\
\text { Tension }\end{array}$ \\
\hline C5 2 layers & 26.5 & 195.5 & 30 & $20 \%$ & 187 & Tension Failure \\
\hline C6 3 layers & 35.1 & 219.8 & 30 & $34.8 \%$ & 197 & $\begin{array}{c}\text { Spalling of } \\
\text { Ferrocemet+ } \\
\text { Crushing }\end{array}$ \\
\hline C7 5 layers & 33.4 & 241.1 & 30 & $48 \%$ & 208.4 & Tension Failure \\
\hline
\end{tabular}

\section{Conclusions:}

Increasing wire mesh from 2 to 5 layers, for both 20 and 30mm ferrocement thickness helps in increasing the ultimate load of the tested strengthened columns by about $20 \%$ to $48 \%$. The experimental results have shown that increasing the thickness from $(20 \mathrm{~mm}$ to $30 \mathrm{~mm}$ ) causes an average increase in the ultimate load of the strengthened columns by ( $6.4 \%$ and $17.4 \%$ ) for 3 and 5 wire mesh layers respectively. It was found that using ferrocement jacket for strengthening the columns causes to spread the cracks at the entire length of the column. The steel fiber or plastic fiber can be used in future studies to enhance ferrocement properties used in strengthening reinforced concrete column.

\section{References:}

1. Takiguchi, K. A., "Shear Strengthening of Reinforced Concrete Columns using Ferrocement Jacket” ACI structural Journal, Vol. 98, No. 5, pp. 696-704, 2001.

2. Abdullah, A. Katsuki, T., "An Investigation into the Behavior and Strength of Reinforced Concrete Columns Strengthened with Ferrocement Jackets", Cement and Concrete Composite, Vol.25, No. 2, pp.233-242, 2003.

3. Mohammad, T. K., Reza, M., "Seismic shear Strengthening of reinforced concrete columns with Ferrocement Jacket", Cement and Concrete Composite, Vol.27, No. 7, PP.834-842, 2005. 
4. Rathish Kumar, P. Oshima, T. Mikami, S. and Yamazaki, T., "Studies on reinforced concrete and Ferrocement Jacketed Columns Subjected To Simulated Seismic Loading", Asian Journal of Civil Engineering (Building And Housing) Vol. 8, No. 2, PP. 215-225, 2007.

5. Kondraivendhan, B. and Pradhan, B., "Effect of Ferrocement Confinement on Behavior of Concrete", Construction and Building Materials, Vol. 23, No. 3, pp. 1218-1222, 2009.

6. Long ,M. J. ,Fan, H.T., and Man, L.O., "Experimental Research on the Strengthening of the Reinforced Concrete Columns by High Performance Ferrocement Laminates", Material Science and Engineering, Vol. 243-249, pp.1409-1415, 2011.

7. Iraqi Standard Specification (5), (1984), "Properties of Normal Portland Cement”, Central Bureau of Measure and Quality Control, Iraq, 1984.

8. British Standards Institute, B.S:1992, “Aggregates from Natural Sources for Concrete”. 